\title{
Artificial Defoliation to Simulate Losses on Production of Bean (Phaseolus vulgaris L. cv. Goytacazes)
}

\author{
Omar Schmildt' ${ }^{1}$ Vinicius de Souza Oliveira1, Dirceu Pratissoli², \\ José Augusto Teixeira do Amaral'2, Marcio Paulo Czepak ${ }^{3}$, Adriel Lima Nascimento1, \\ Edilson Romais Schmildt ${ }^{3}$ \\ ${ }^{1}$ Postgraduate Program in Tropical Agriculture, Federal University of Espírito Santo, São Mateus, ES, Brazil \\ ${ }^{2}$ Department of Agronomy, Federal University of Espírito Santo, Alegre, ES, Brazil \\ ${ }^{3}$ Departament of Agrarian and Biological Sciences, Federal University of Espírito Santo, São Mateus, ES, Brazil \\ Email: sou zaoliveiravini@gmail.com
}

How to cite this paper: Schmildt, O., de Souza Oliveira, V., Pratissoli, D., do Amaral, J.A.T., Czepak, M.P., Nascimento, A.L. and Schmildt, E.R. (2019) Artificial Defoliation to Simulate Losses on Production of Bean (Phaseolus vulgaris L. cv. Goytacazes). Agricultural Sciences, 10, 1023-1031. https://doi.org/10.4236/as.2019.108077

Received: July 6, 2019

Accepted: August 9, 2019

Published: August 12, 2019

Copyright () 2019 by author(s) and Scientific Research Publishing Inc. This work is licensed under the Creative Commons Attribution International License (CC BY 4.0).

http://creativecommons.org/licenses/by/4.0/

\begin{abstract}
The reduction of foliar area can cause yield reduction in common bean crops. The objective of this work was to verify which is the effect of different defoliation levels realized in several development stages of common bean (Phaseolus vulgaris L. cv. Goytacazes) over yield, weight of 100 seeds and number of pods per plant. The experimental design was randomized blocks, in a split-plot arrangement with five replications. The plot corresponded to the five defoliation epochs (first trifoliate leaf, flowering, pods formation, pods filling, and dry pods). In each plot, the split plot was represented by the four defoliation levels $(0 \%, 33 \%, 67 \%$ and $100 \%)$. It was observed a decrease of yield for all levels defoliation considering all development stages, except for dried pods. The highest decrease was detected for flowering and pods formation. Through the regression analysis got a greater reduction in yield with $100 \%$ defoliation made at 42 days after emergence. The evaluation parameter that showed better relation with yield was a number of pods per plant.
\end{abstract}

\section{Keywords}

Common Bean, Defoliation, Grain Productivity, Mass of Seeds, Pods

\section{Introduction}

In Brazil, there is a good availability of improved varieties of common bean and adapted to the different regions, which facilitates the development of the crop. However, the lack of quality seeds in the desired quantity constitutes a serious 
problem for the sector [1].

The reductions in bean production found in Brazil are mainly caused by coleopterans Diabrotica speciosa, Cerotoma sp. and Lagria vilosa, and by lepidoptera Hedylepta indicata, Pseudoplusia includens and Urbanus proteus, due to the reduction of leaf area [2] [3]. Also, the reduction of leaf area can also be caused by fungal, bacterial and viral diseases that can cause leaf falls [4].

Pest damage in bean crop can be observed from sowing until the beans are dry in the pods or even stored, and due to the diversity of species that occur, virtually all plant structures have been shown to be susceptible [5], especially if the occurrence of the pests coincides with the period from germination to flowering [2]. This is because the production is directly related to the photosynthetic capacity of the plants and, therefore, depending on the leaf area index [6] [7]. Thus, plants subjected to defoliation may have reduced production, mainly due to the decrease in the number of pods [4] [8] [9] [10], in seed mass and grain weight [3] [11], which leads to losses in production from $30 \%$ to $90 \%$ [5].

The significant effect on loss of grain yield at harvest varies due to the time and intensity of defoliation [3] [4] [9] [10] [12] [13], therefore, there is a close interrelation between production and defoliation, depending on the stage of development of the plants [14]. However, the results of studies that indicate the defoliation season more damaging to the bean crop are quite contrasting. [3] [15] observed greater damage to the crop when defoliation was performed at the beginning of pod formation. [9] and [16] found that flowering was the most damaging stage. In contrast, [14] observed that the defoliation of $25 \%$ in plants with 10 and 17 days of age did not significantly decrease the production, but in plants with more than 24 days of age the defoliation at all levels reduced the production of the bean. Other authors [4] [8] [11] [12] [13] [17] concluded that there was no more harmful stage due to defoliation, but a period ranging from flowering to pod filling.

It has been verified a varied behavior of the bean cultivars against simulated defoliation, as reported by [9], for "Carioca" and "Rosinha", [16], for the cultivar "Pérola", [13], for the cultivar "Capixaba Precoce", [13], for the cultivar "Xamego" and [10] for the cultivar "Caupi". However, no information is available on the levels of leaf area reduction of Goytacazes bean, in relation to the defoliation caused mainly by insect pests, which cause significant losses in grain production in the southern state of Espírito Santo.

The objective of this work was to verify the effect of different levels of artificial defoliation of Goytacazes bean at different stages of development of the plants grown in field conditions in the south of the State of Espírito Santo, on the production of grains, number of pods plant ${ }^{-1}$ and mass of 100 seeds.

\section{Material and Methods}

The work was carried out in the Rive experimental area of the Center of Agrarian Sciences of the Federal University of Espírito Santo, located in the city of 
Alegre-ES, Brazil (Latitude: $20^{\circ} 45^{\prime} \mathrm{S}$, Longitude: $41^{\circ} 29^{\prime} \mathrm{W}$, Altitude: $150 \mathrm{~m}$ ), during the months of October to December, using common bean (Phaseolus vulgaris L. cv. Goytacazes).

The soil where the experiment was implanted is of the type clayey [18] and had the following chemical characteristics: $\mathrm{pH}=6.9 ; \mathrm{Al}^{3+}=0.0 \mathrm{cmol}_{c} \cdot \mathrm{dm}^{-3} ; \mathrm{Ca}^{2+}$ $=3.7 \mathrm{cmol}_{\mathrm{c}} \cdot \mathrm{dm}^{-3} ; \mathrm{Mg}^{2+}=1.6 \mathrm{cmol}_{\mathrm{c}} \cdot \mathrm{dm}^{-3} ; \mathrm{P}=12 \mathrm{mg} \cdot \mathrm{dm}^{-3} ; \mathrm{K}=90 \mathrm{mg} \cdot \mathrm{dm}^{-3}$. No fertilization was done during the conduction of this work, because the nutritional levels were adequate for the bean crop [19].

The experimental design was a randomized block design, with subdivided plots, with five replications. The plots were constituted by five periods of defoliation [20]: V3 - first trifoliolate leaf (at 15 days after emergence), R6-flowering (at 30 days after emergence), R7-pod formation (at 45 days after emergence), R8-pod filling (at 60 days after emergence) and R9-dry pods (75 days after emergence); and the subplots contained four levels of defoliation: $0 \%, 33 \%, 67 \%$ and $100 \%$ of trifoliolate leaves removal. Each plot was composed of two rows of $3 \mathrm{~m}$ in length. The spacing used was $0.5 \mathrm{~m}$ between rows and $0.10 \mathrm{~m}$ between plants. As borders, two rows of the cultivar Capixaba Precoce were planted, sown in the same plot spacing, around each block.

To obtain the defoliation levels, the manual removal of leaflets obeyed the following pattern for all removal times: 1) Plant without defoliation; 2) plant with $33 \%$ of defoliation (removal of 1 leaflet per leaf); 3) plant with $67 \%$ defoliation (removal of 2 leaflets per leaf); 4) plant with 100\% defoliation (removal of all leaflets). The defoliation was performed manually, without the use of any cutting instrument.

The cultural treatments employed were those commonly recommended for bean culture. Sprinkler irrigations were done throughout the crop cycle in order to maintain the experimental area soil in the field capacity. Spraying with insecticide and fungicide were done preventively, to avoid the action of pests or diseases that would reduce the leaf area, since this should be done, according to the treatments, only in an artificial way. The insecticides used were trichorphon ( 800 $\left.\mathrm{g} \cdot \mathrm{ha}^{-1}\right)$, applied at 10 and 40 days after sowing, and methamidaphos (400 g.ha $\left.{ }^{-1}\right)$, applied at 25 and 55 days after sowing. The fungicides used were based on chlorothalonil (70 grams per 100 liters of water), applied at 10 and 40 days after sowing, and cuprous oxide (107 grams per 100 liters of water) applied at 25 and 55 days after sowing.

The plants to be harvested, at 92 days after sowing, were separated by subplot and the following variables were evaluated: number of pods per plant, mass of 100 seeds, productivity $\left(\mathrm{g} \cdot \mathrm{plot}^{-1}\right)$, which was later converted into $\mathrm{kg} \cdot \mathrm{ha} \mathrm{a}^{-1}$ for statistical analysis.

The means of the variables were analyzed statistically by the F test and regression, being the analyzes made atraves the program GENES [21].

\section{Results and Discussion}

There was a significant difference between the mean levels of defoliation $(L D)$ 
and stages of development $(S D)$, beyond the interaction between these factors in relation to the variables productivity and number of pods per plant. As for the variable mass of 100 seeds, there was a significant difference only for $L D$ (Table 1).

Productivity was linearly reduced as a function of $L D$ at all stages of development (Figure 1). It was observed that defoliation was more damaging in stages R6 (flowering) and R7 (pod formation), with a reduction of about $180 \mathrm{~kg} \cdot \mathrm{ha}^{-1}$ for every $10 \%$ of defoliation, and in stage R8 (filling of pods), with a productivity reduction of approximately $120 \mathrm{~kg} \cdot \mathrm{ha}^{-1}$ for every $10 \%$ of defoliation.

Also in Figure 1, it can be noted that for the stages V3 (first trifoliolate leaf) and R9 (dry pods) the losses were approximately $40 \mathrm{~kg} \cdot \mathrm{ha}^{-1}$ for every $10 \%$ of defoliation. These results are similar to those observed by several researchers in other cultivars [8] [11] [12] [13] [17]. In contrast, the results obtained in this study differ from those reported by [9], with cultivars Carioca and Rosinha, and by [16], with the cultivar Pérola, in which the defoliation at the R6 (flowering) stage caused larger reductions in production. It differs also from the results verified by [15] and by [3] who noticed that the R7 stage was the most impaired due to defoliation.

Productivity as a function of $S D$ equivalent in days after emergence $(D A E)$ decreased, following the quadratic model, to $67 \%$ and $100 \%$ of defoliation (Figure 2).

It can be observed in Figure 2 that the greatest loss of estimated productivity (84.1\%) occurred with $100 \%$ of defoliation, done at $44 D A E$. With $67 \%$ of defoliation, the greatest productivity losses (29.1\%) occurred at $49 D A E$. [15] Recorded average productivity losses of $59.4 \%$ and $58.5 \%$ with $100 \%$ defoliation in the cultivars Carioca and Rosinha, respectively. [14] working with the cultivar Pérola,

Table 1. Abstract of the analysis of variance for the variables productivity, number of pods per plant and mass of 100 seeds in the goytacazes cultivar influenced by four levels of defoliation $(L D)$ in five stages of development $(S D)$.

\begin{tabular}{|c|c|c|c|c|}
\hline \multicolumn{5}{|c|}{ Mean Squared } \\
\hline SV & $\mathrm{DF}$ & $\begin{array}{l}\text { Productivity } \\
\left(\mathrm{kg} \cdot \mathrm{ha}^{-1}\right)\end{array}$ & $\begin{array}{l}\text { Pods per Plant } \\
\left(\mathrm{n}^{\circ}\right)\end{array}$ & Mass of 100 Seeds (g) \\
\hline Bloc & 4 & $2,617,321.94$ & 57.09 & 40.17 \\
\hline SD & 4 & $773,651.97^{* *}$ & $55.05^{* *}$ & $2.73 \mathrm{~ns}$ \\
\hline Error a & 16 & $120,379.59$ & 9.42 & 3.98 \\
\hline $\mathrm{LD}$ & 3 & $6,392,553.46^{* *}$ & $146.16^{\star *}$ & $29.74^{* *}$ \\
\hline$S D \times L D$ & 12 & $651,795.31^{* *}$ & $186.95^{* *}$ & $2.03^{* *}$ \\
\hline Error b & 60 & $73,746.08$ & 18.14 & 1.31 \\
\hline Average & & 1871.94 & 10.09 & 22.27 \\
\hline $\mathrm{CV}(\%)_{\mathrm{plot}}$ & & 18.53 & 7.61 & 8.97 \\
\hline $\mathrm{CV}(\%)_{\text {sub-plot }}$ & & 14.51 & 5.44 & 5.15 \\
\hline
\end{tabular}

${ }^{\text {ns }}$ Not significant; ${ }^{* *}$ Significant at $1 \%$ probability by $\mathrm{F}$ test. 


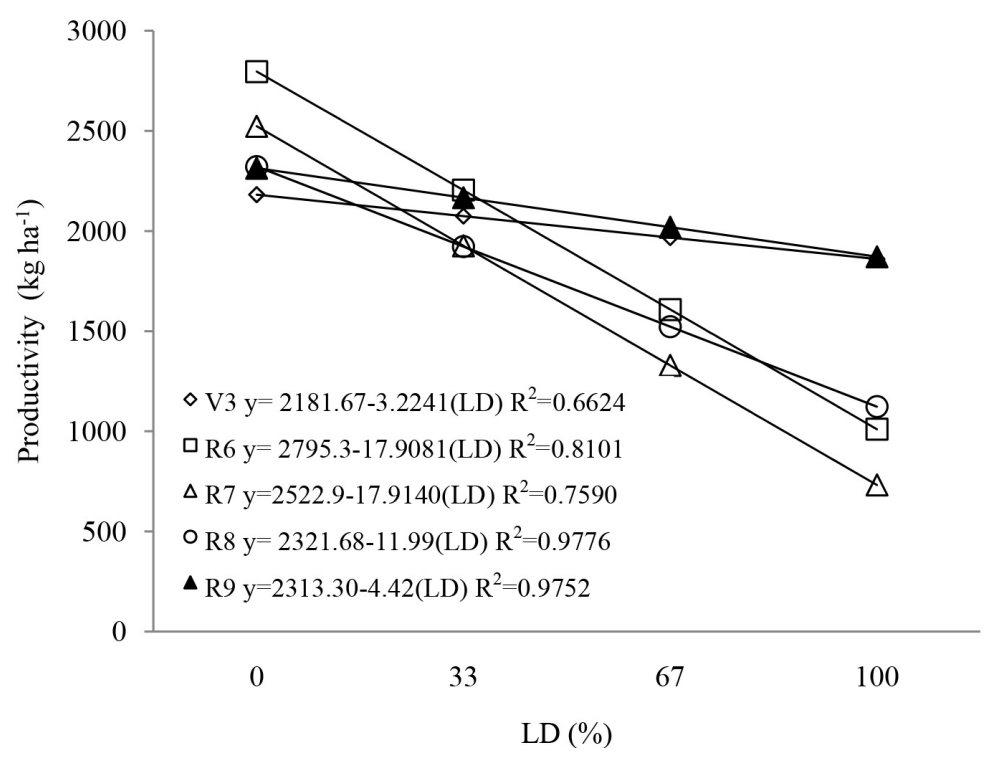

Figure 1. Productivity of Goytacazes bean cultivar as a function of the levels of defoliation (LD, \%) applied at different stages of development (V3, R6, R7, R8 and R9, corresponding to, respectively, 15, 30, 45, 60 and 75 days after emergence).

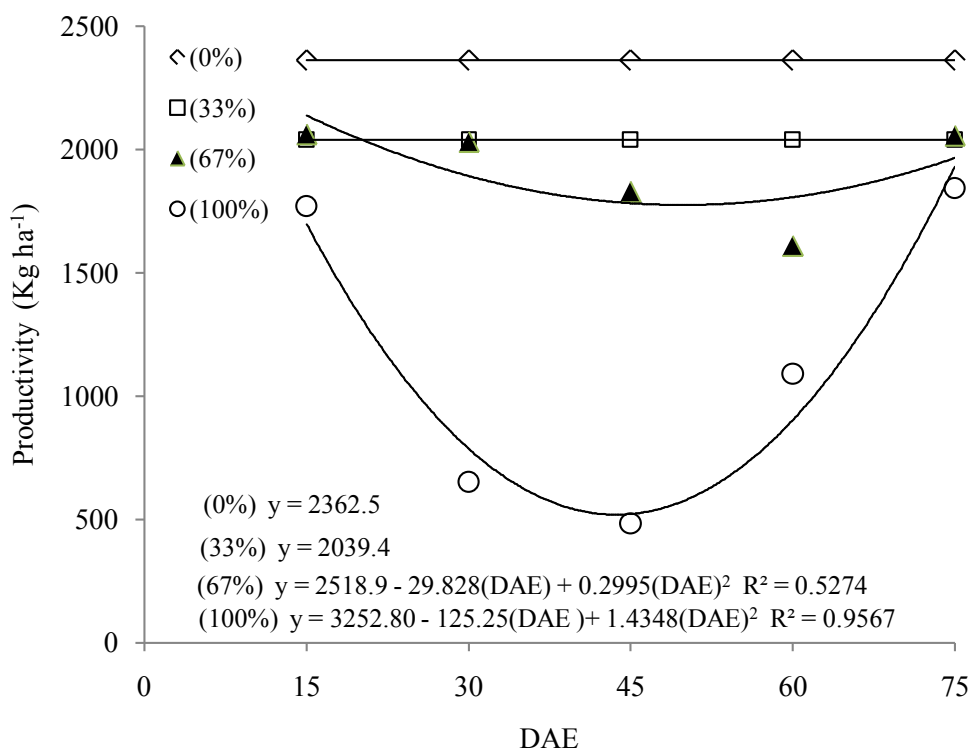

Figure 2. Productivity of Goytacazes bean cultivar for different levels of defoliation in five stages of development (V3, R6, R7, R8 and R9), equivalent in days after emergence (DAE) in 15, 30, 45, 60 and 75 days, respectively.

noted a reduction in productivity only when the defoliation was $50 \%$ or more, suggesting some stress.

The loss of leaf area in common bean affects the yield components, due to changes in the physiological activity of the plants, ultimately influencing the crop productivity [7] [15]. The variations of defoliation responses verified in several studies demonstrate the variability of the genotypes and should not be extrapolated the results for the different cultivars. 
The number of pods per plant was affected by $L D$ at the development stages V3, R6 and R7 following a linear model (Figure 3). The reduction was more pronounced in R6 and R7, with a decrease of about 0.7 pods per $10 \%$ of defoliation, which corresponded to the loss of about $50 \%$ of the pods in relation to the plants without defoliation. [13] observed average reductions of $58.1 \%$ and $55.5 \%$ of the number of pods for the cultivar Capixaba Precoce when $100 \%$ defoliation was applied at the R6 and R7 stages, respectively. [3] also observed a reduction in the number of pods with $100 \%$ of defoliation in cultivar Xamego, but this reduction was more pronounced in R7 (64\%) than in R6 (41\%). [4] obtained in cultivar Carioca Precoce a reduction of $64.5 \%$ and $62.2 \%$ of the number of pods in stages R6 and R7, respectively, when defoliation was $100 \%$.

In legumes, photoassimilates, produced by the leaves, are accumulated intermediates in the branches and later translocated to the pods [22]. [23], in a study with soybean, reported that, due to the increase of the size of the drains during flowering times and during the filling of the pods, peaks of photosynthetic activity occur, indicating a greater need of photoassimilates at these stages of plant development. The authors noted that defoliation during these phases cause greater losses in the number of pods, because current photosynthesis was not sufficient to meet the demand in those times. It may be suggested that probably the same with cultivar Goytacazes, due to limitations in the availability of photoassimilates, by the decreases in source/drainage ratios.

Regarding $S D$, the number of days after emergence $(D A E)$ can explain the number of pods per plant according to the quadratic model, when the plants were submitted to defoliation of $67 \%$ and $100 \%$ (Figure 4). It can be noted that the lowest number of pods per plant (5.88) occurred with $100 \%$ of defoliation at $38 D A E$, while in the absence of defoliation an average of 11 pods per plant was produced. It should be noted that the lowest yields coincided with the R6 to R8 stages (30 to $60 D A E$ ) as shown in Figure 1.

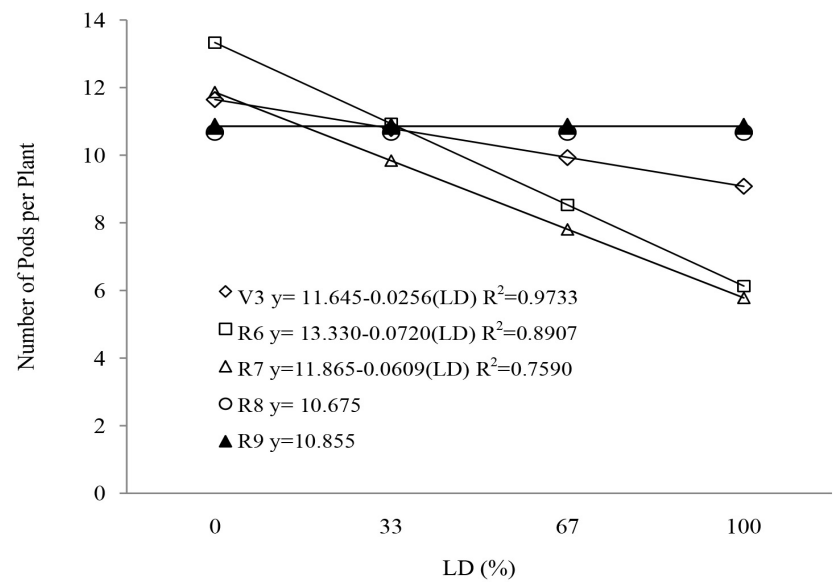

Figure 3. Number of pods per plant of the Goytacazes bean cultivar in function of the levels of defoliation (LD, \%) applied at different stages of development (V3, R6, R7, R8 and R9, corresponding to 15, 30, 45, 60 and 75 days after emergence). 


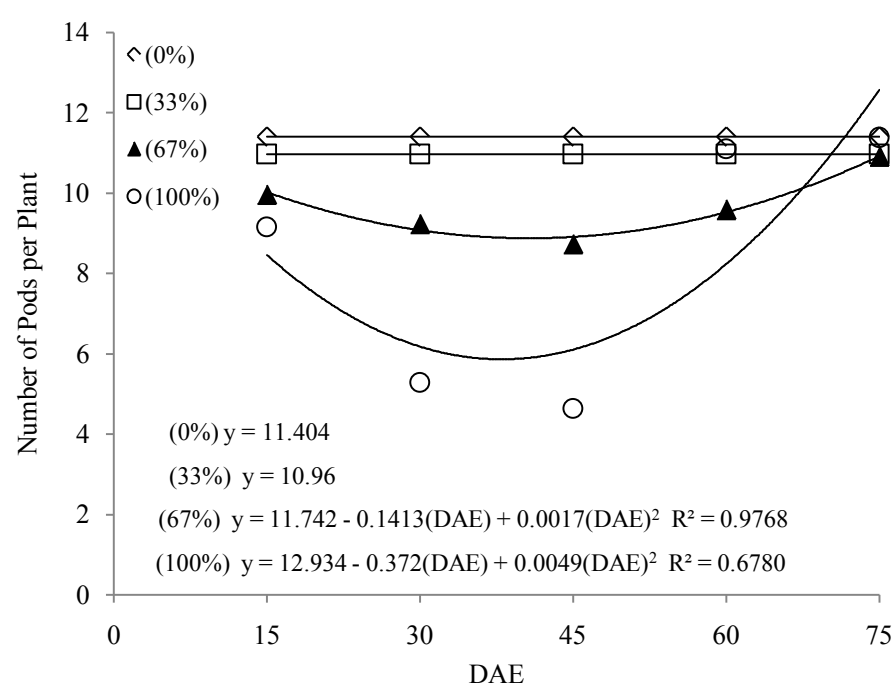

Figure 4. Number of pods per plant of Goytacazes bean cultivar for different levels of defoliation in five stages of development (V3, R6, R7, R8 and R9), equivalent in days after emergence (DAE) in: 15, 30, 45, 60 and 75 days.

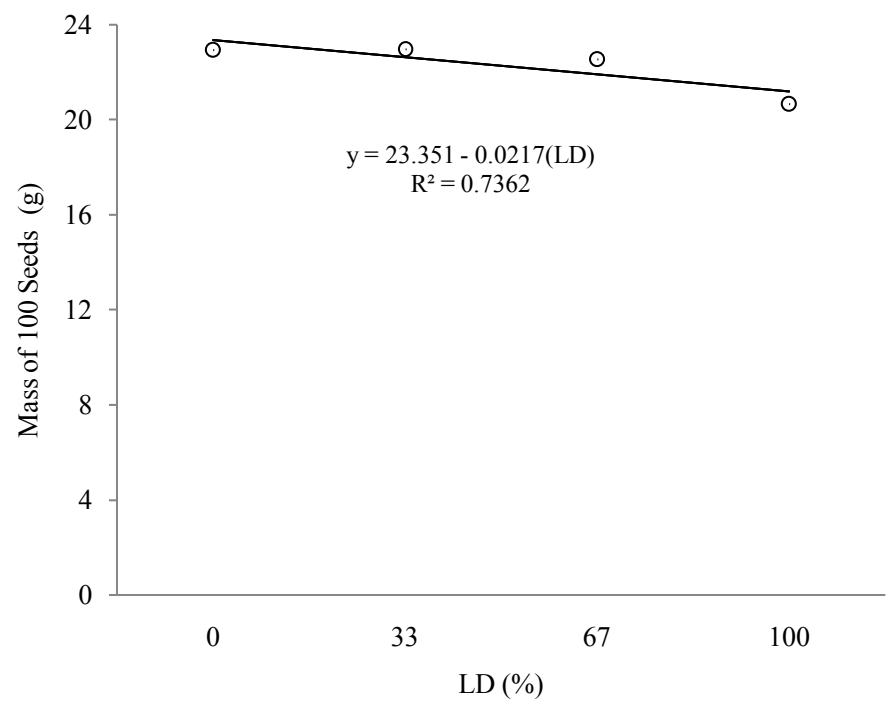

Figure 5. Mass of 100 seeds of Goytacazes bean cultivar in function by levels of defoliation $(L D, \%)$.

The mass of 100 seeds in function of $L D$ was shown to a linear reduction (Figure 5). An average of $23.35 \mathrm{~g}$ was obtained for every 100 seeds in the absence of defoliation and $21.18 \mathrm{~g}$ for $100 \%$ of defoliation corresponding to $9.29 \%$ reduction. The reduction of grain mass due to defoliation in common bean was also observed by other researchers [3] [10] [11] [12]. This reduction, however, was lower than that observed for number of pods per plant (Figure 3 and Figure 4), as also observed by other authors [3] [9] [24].

The removal of leaves and consequent reduction of the photosynthetically active area certainly causes reduction in the yield components, by reduction in the 
amount of photoassimilates produced [7] reported that the reduction of bean leaf area caused by the beetle Epilachna varivestis causes a reduction of the photosynthetic rate in plants, associated mainly with the use of phosphate and the need for regeneration of ribulose 1,5-bisphosphate carboxylase (Rubisco).

\section{Conclusion}

Defoliation of $33 \%$ can already be considered harmful to the development of common bean. The greatest productivity declines occurred with defoliation during flowering and filling of the pods. Reduction of leaf area at 75 days of plant development, did not significantly interfere in productivity, coinciding with the end of the cycle. The number of pods per plant is the yield component that most affected productivity.

\section{Conflicts of Interest}

The authors declare no conflicts of interest regarding the publication of this paper.

\section{References}

[1] Posse, S.C.P., Riva-Souza, E.M., Silva, G.M., Fasolo, L.M., Silva, M.B. and Rocha, M.A.M. (2010) Informações técnicas para o cultivo do feijoeiro-comum na região central-brasileira: 2009-2011. Incaper, Vitória.

[2] Batista, G.C., Vendramin, J.D. and Marchini, I.C. (1992) Pragas do amendoim, feijoeiro e caupi: Curso de entomologia aplicada à agricultura. FEALQ, Piracicaba, 760.

[3] Schmildt, E.R., Amaral, J.A.T., Pratissoli, D. and Reis, E.F. (2010) Influence of Artificial Defoliation to simulate Losses in Production of Beans (Phaseolus vulgaris $\mathrm{L}$. cv. xamego). Arquivos do Instituto Biológico, 77, 457-463.

[4] Pratissoli, D., Schmildt, E.R., Amaral, J.A.T. and Schmildt, O. (2012) Levels of Artificial Defoliation to Simulate Yield Losses of Common Bean. Scientia Agraria Paranaensis, 11, 68-76. https://doi.org/10.18188/1983-1471/sap.v11n3p68-76

[5] Tartarin, B.B.G., Barros, W.S. and Souza, L.C.D. (2016) Major Pests in Common Bean Crop. Revista Conexão Eletrônica, 13, 1-18.

[6] Watson, D.J. (1947) Comparative Physiological Studies on the Growth of Field Crops. I. Variation in Net Assimilation Rate and Leaf Area between Species and Varieties, and within and between Years. Annals of Botany, 11, 41-76. https://doi.org/10.1093/oxfordjournals.aob.a083148

[7] Peterson, R.K.D., Higley, L.G., Haile, L.G. and Barrigossi, A.F. (1998) Mexican Bean Beetle (Coleoptera: Coccinellidae) Injury Affects Photosynthesis of Glycine Max and Phaseolus vulgaris. Environmental Entomology, 27, 373-381. https://doi.org/10.1093/ee/27.2.373

[8] Xia, M.Z. (1993) Effects of Faba Bean Leaves in Different Positions on the Yield and Photosynthetic Compensation after Defoliation. Journal of Agronomy and Crop Science, 171, 145-152. https://doi.org/10.1111/j.1439-037X.1993.tb00125.x

[9] Moura, G.M. (1999) Effect of Defoliation on Bean Yield. Pesquisa Agropecuária Brasileira, 34, 57-62. https://doi.org/10.1590/S0100-204X1999000100008 
[10] Smiderle, O.J., Lima-Primo, H.E., Barbosa, H.D. and Souza, A.G. (2017) Effect of Defoliation on Production Components at Different Growth Stages of Cowpea. Revista Ciência Agronômica, 48, 840-847. https://doi.org/10.5935/1806-6690.20170099

[11] Hohmann, C.L. and Carvalho, S.M. (1983) Effect of Defoliation on Yield of Beans (Phaseolus vulgaris Linnaeus, 1753). Anais da Sociedade Entomológica do Brasil, 12, 3-9.

[12] Schaafsma, A.W. and Ablett, G.R. (1994) Yield Loss Response of Navy Bean to Partial or Total Defoliation. Journal of Production Agriculture, 7, 202-205. https://doi.org/10.2134/jpa1994.0202

[13] Pratissoli, D., Schmildt, E.R., Reis, E.F. and Thuler, R.T. (2001) Influence of Simulated Defolation on the Yield and Other Agronomic Characteristics of Common Bean. Revista Ceres, 48, 17-24.

[14] Silva, A.L., Veloso, V.R.S., Crispim, C.M.P., Braz, V.C., Santos, L.P. and Carvalho, M.P. (2003) Effect of Leaf Surface Reduction in Common Bean (Phaseolus vulgaris L.). Pesquisa Agropecuária Tropical, 33, 83-87.

[15] Moura, G.M.A. and Mesquita, J.H.L. (1982) Influência do desfolhamento artificial no rendimento de grãos do feijoeiro (Phaseolus vulgaris L.), no Acre. In: Reunião Nacional de Pesquisa de Feijão, EMBRAPA/CNPAF, Goiânia, 124-127.

[16] Fazolin, M. and Estrela, J.L.V. (2003) Effect of Different Levels of Defoliation on Productivity of Common Beans (Phaseolus vulgaris L. cv. Perola). Ciência e Agrotecnologia, 27, 978-984. https://doi.org/10.1590/S1413-70542003000500002

[17] Gálvez, G.E., Galindo, J. and Alvarez, G. (1977) Defoliación artificial para estimar perdidas por daños foliares en frijol (Phaseolus vulgaris L.). Turrialba, 27, 143-146.

[18] Embrapa (2018) Sistema Brasileiro de Classificação de Solos. 5th Edition, revista e ampliada, Embrapa, Brasília.

[19] Prezotti, L.C., Gomes, J.A., Dadalto, G.G. and Oliveira, J.A. (2017) Manual de Recomendação de Calagem e Adubação para o Estado do Espírito Santo. 5th aproximação. SEEA/INCAPER/CEDAGRO, Vitória, 305.

[20] Fernández, F., Gepts, P. and Lopes, M. (1985) Etapas de desarollo en la planta de frijol. In: López, M., Fernández, F. and Schoonhoven, A., Eds., Frijol: Investigación y producción, PNUD, CIAT, Cali, 61-78.

[21] Cruz, C.D. (2016) Genes Software-Extended and Integrated with the R, Matlab and Selegen. Acta Scientiarum Agronomy, 38, 547-552. https://doi.org/10.4025/actasciagron.v38i3.32629

[22] Subbarao, G.V., Johansen, A.C., Slinkard, R.C., Rao, N., Saxena, N.P. and Chauhan, Y.S. (1995) Strategies for Improving Drought Resistance in Grain Legumes. Critical Reviews in Plant Sciences, 14, 469-523. https://doi.org/10.1080/07352689509701933

[23] Sediyama, T., Pereira, M.G., Sediyama, C.S. and Gomes, J.L.L. (1985)Cultura da soja: $1^{a}$ parte. UFV, Viçosa, 96.

[24] Coelho, A.D.F., Fernandes, A.D., Cardoso, A.A., Cruz, C.D., Araújo, G.A.A., Furtado, M.R. and Amaral, C.L.F. (2002) Heritabilities and Correlations of Common Bean Yield and Its Primary Components, in the Spring-Summer and Summer-Fall Cultivation Seasons. Ciência Rural, 32, 211-216. https://doi.org/10.1590/S0103-84782002000200005 